\title{
PENGEMBANGAN BAHAN AJAR BERBASIS MULTIMEDIA DENGAN STRATEGI PEMBELAJARAN KOOPERATIF (COOPERATIVE LEARNING) PADA MATA DIKLAT ANALISIS MIKROBIOLOGI DI SMK
}

\author{
Sri Hartini ${ }^{1}$ dan Julaga Situmorang ${ }^{2}$ \\ SMK Negeri 3 Medan $^{1}$ dan Universitas Negeri Medan ${ }^{2}$ \\ srismk3@yahoo.co.id ${ }^{1}$
}

\begin{abstract}
Abstrak: Penelitian ini bertujuan untuk menghasilkan bahan ajar berbasis multimedia yang layak dan memenuhi syarat sebagai media pembelajaran yang baik dan lebih efektif dibanding dengan pemakaian bahan ajar modul. Metode penelitian dilakukan dengan menggunakan langkah-langkah metode Research and Development $(R \& D)$ Borg and Gall dan dilanjutkan dengan Uji Efektifitas produk dalam proses pembelajaran. Hasil penelitian menunjukkan bahwa kualitas media pembelajaran yang dikembangkan secara keseluruhan memiliki kategori Sangat Baik (89,48\%) menurut ahli dan siswa sehingga dapat disimpulkan bahwa media pembelajaran layak digunakan sebagai sumber belajar pada mata diklat analisis mikrobiologi. Hasil uji efektifitas produk pada proses pembelajaran dengan menggunakan strategi pembelajaran kooperatif menunjukkan bahwa pembelajaran dengan menggunakan multimedia pembelajaran lebih efektif $(88,91 \%)$ dibanding dengan pembelajaran menggunakan modul (82,03\%).
\end{abstract}

Kata Kunci: bahan ajar multimedia, strategi pembelajaran kooperatif, analisis mikrobiologi

\begin{abstract}
This study aims to produce a multimedia-based instructional materials appropriate and qualified as a good medium of learning and more effectively than with the use of teaching materials module. The method of research is done by using the steps the Research and Development $(R \& D)$ Borg and Gall and proceed with test product effectiveness in the learning process. The results showed that the quality of the media that was developed as a whole has the Excellent category (89.48\%) according to the experts, and thus it can be concluded that the students learning media fit for use as a source of learning on training microbiological analysis. The results of effectiveness product test on the learning process by using cooperative learning strategies showed that learning by using multimedia learning was more effective $(88,91 \%)$ compared with learning by using module $(82,03 \%)$.
\end{abstract}

Keywords : Multimedia Instructional Materials, effectiveness

\section{PENDAHULUAN}

Mata diklat analisis Mikrobiologi merupakan mata diklat produktif yang harus pelajari dari siswa semester 3 Jurusan Kimia Analisis di SMK Negeri 3 Medan. Mata diklat ini merupakan mata diklat keilmuan dan keterampilan dengan jumlah 4 jam teori dan praktikum di laboratorium. Teori yang diberikan merupakan dasar bagi pelaksanaan praktikum di laboratorium, sehingga satu dengan lainnya merupakan satu kesatuan.

Menurut hasil jajak pendapat yang dilakukan terhadap siswa Jurusan Kimia Analisis yang pernah mengikuti mata diklat ini, diperoleh informasi permasalahan yang dialami siswa, terkait penguasaan materi pada mata diklat Analisis Mikrobiologi, ternyata hampir
75\% menyatakan : (1) sulit memahami konsepkonsep dari materi, (2) sulit mengenali jenis dan bentuk dari contoh-contoh yang diberikan pada modul, (4) adanya rasa jenuh siswa dengan pengulangan materi disebabkan belum tuntas, sehingga membuat suasana kelas kurang menyenangkan, dan (5) materi pada modul tidak memberikan contoh dan gambaran yang jelas tentang materi kepada siswa.

Dari analisis permasalahan diatas bila dikaitkan dengan hasil belajar, menunjukkan hasil belajar kurang memuaskan, hal ini terlihat dari hasil belajar mata diklat Analisis Mikrobilogi pada tiga tahun terakhir menunjukkan nilai rata-rata hasil belajar masih dibawah nilai KKM yaitu 6,00. Dari gambaran hasil belajar yang diperoleh, maka perlu upaya 
untuk memperbaiki proses belajar baik strategi, metode dan pemanfaatan berbagai sumber belajar, hal ini penting karena karakteristik materi-materi pada mata diklat Analisis Mikrobiologi dikategorikan bersifat konkrit, abstrak, dan simulatif, memerlukan alat bantu untuk membuktikannya dan memerlukan permodelan berupa gambar atau aktifitas yang dimodelkan.

Proses pembelajaran yang selama ini dilakukan dengan menggunakan modul sebagai sumber belajar utama. Pada proses pembelajaran siswa sangat jarang diajak untuk berdiskusi tentang materi yang dipelajari. Padahal metode berdiskusi sangat efektif bila diterapkan di lingkungan pmbelajaran orang dewasa, akan lebih baik hasilnya bila sumber belajar siswa tidak hanya bahan cetak (modul) yang telah diwajibkan sebagai pegangan siswa, tetapi juga non cetak (web,internet, Compact Disk, Video Compact Disk, multimedia pembelajaran dan sebagainya).

Selain itu dengan sumber belajar non cetak diharapkan dapat mengubah pemikiran siswa bahwa pengetahuan yang tidak tampak mata (abstrak) secara langsung) dapat dikonkritkan melalui proses ilustrasi dan visualisasi dalam sumber belajar tersebut. Penggunaan multimedia sebagai salah satu sumber belajar non cetak dalam dunia pendidikan merupakan paradigma perubahan secara radikal dalam proses pembelajaran dari metode pembelajaran secara tradisional atau "pembelajaran transmisi" (siswa pasif) ke model "siswa aktif".

Media dan teknologi dapat memberikan kontribusi yang sesuai diharapkan terhadap kualitas hasil belajar siswa, bila diintegrasikan dengan kegiatan belajar. Diketahui komputer sebagai alat elektronik yang termasuk kategori multimedia mampu melibatkan berbagai indera dan organ tubuh, seperti: telinga (audio), mata (visual), dan tangan (kinetik) yang dengan libatannya dalam pembelajaran memungkinkan informasi atau pesan yang disampaikannya mudah dimengerti (Munadi, 2012:148). Pernyataan tersebut di dukung oleh Jacqueline McLaughlin \& Daniel A. Arbeider dalam artikelnya yang berjudul Evaluating Multimedia-Learning Tools Based on Authentic Research Data That Teach Biology Concepts and Environmental Stewardship berpendapat bahwa multimedia berbasis riset dalam pembelajaran (1) mendukung pengajaran standards-based, (2) menguatkan pemikiran komplek dan memecahkan masalah, (3) memberikan keterampilan untuk melakukan riset, (4) mengukur kinerja siswa, dan (5) mengkonkritkan pengetahuan yang sebenarnya.

Ditinjau dari karakteristik mata diklat dan metode yang digunakan, proses pembelajaran dilakukan dengan mendekatkan obyek belajar dengan obyek aslinya, artinya bahwa kegiatan pembelajaran yang berlangsung harus didukung oleh sumber belajar yang dikaitkan dengan lingkungan sekitar siswa baik lingkungan alam, sosial dan budaya kemasyarakatan. Bila sumber belajar yang diharapkan tidak tersedia dan terwakili oleh lingkungan sekitar siswa, maka perlu adanya pengembangan sumber belajar tersebut.

Untuk mata diklat Analisis Mikrobiologi, solusi yang dapat ditempuh adalah dengan mengembangkan penyajian materi dalam bentuk teks, gambar, foto, dan video pembelajaran yang dapat digunakan oleh (1) guru untuk menjelaskan konsep yang sulit dipahami sehingga siswa lebih mudah memahaminya, dan (2) siswa sebagai tambahan sumber belajar berupa media pembelajaran yang dikemas dalam bentuk CD pembelajaran dalam mempelajari media pertumbuhan mikroba secara mandiri, sehingga memberi kemudahan belajar serta mampu mengoptimalkan pemahaman pada struktur kognitif siswa.

Pembelajara yang hanya mengandalkan penjelasan secara verbal memang banyak terjadi. Metode ini dirasa paling ampuh untuk mentransfer ilmu berupa konsep dasar, tetapi bukan untuk menjelaskan bagaimana media pertumbuhan mikroba dapat dipahami dengan benar dan memberikan pengalaman belajar pada siswa langsung melalui visualisasi yang diberikan melalui media pembelajaran. Hasil penelusuran di lapangan menyatakan bahwa pemanfaantan media dan teknologi pembelajaran di Sekolah Menengah Kejuruan memang sangat minimal, artinya belum seoptimal yang dilakukan di tingkat pendidikan dasar.

Bersumber pada laporan hasil studi kajian standarisasi dan pemanfaatan media pembelajaran di Perguruan Tinggi, dari 826 jumlah pemanfaatan jenis media dan teknologi pembelajaran di Perguruan Tinggi hanya $29,66 \%$ yang memanfaatkan media berbasis komputer, selebihnya menggunakan media cetak $(46,13 \%)$, media audio visual $(10,53 \%)$, dan media laboratorium $(13,68 \%)$. Menilik hasil penelitian tersebut maka media cetak lebih mendominasi dan banyak digemari untuk 
digunakan sebagai salah satu sumber belajar di Perguruan Tinggi, sedangkan media lainnya kurang mendapat perhatian (Padmo, 2011).

Menurut Hamalik (2004:11)

menyatakan bahwa para guru/guru dituntut agar mampu memahami, menggunakan alat-alat yang tersedia dalam upaya mencapai tujuan pembelajaran yang diharapkan. Untuk itu pengajar harus memiliki pengetahuan dan pemahaman yang cukup tentang media pembelajaran. Lebih lanjut dikatakan bahwa masalah yang timbul tidak semudah yang dibayangkan pengajar yaitu guru yang menguasai materi pelajaran, sebagian besar tidak mampu menghadirkan bentuk pembelajaran dalam komputer, sedangkan ahli komputer yang mampu merealisasikan segala hal dalam komputer biasanya tidak menguasai materi pelajaran. Hal tersebut menjadi dilema para guru dikarenakan keterbatasan akan penggunaan sarana komputer yang kurang maksimal, padahal ketercapaian tujuan proses belajar mengajar tersebut sangat dipengaruhi peran pentingnya media pembelajaran dalam hal ini media bukan hanya buku teks atau modul tetapi sudah beranjak ke perkembangan Ilmu Pengetahuan dan Teknologi (IPTEK) yang beragam jenisnya. Minimalnya ketersediaan media dan teknologi pembelajaran di sekolah menjadi salah satu penyebabnya adalah tidak banyak sekolah yang mampu mengupayakan sendiri peningkatan kuantitas dan kualitas media.

Hal ini terjadi karena tidak adanya kerjasama dengan instansi lain yang berhubungan dengan pengadaan media pembelajaran di sekolah. Akibatnya yang terjadi adalah media untuk pembelajaran di sekolah hanya mengandalkan bahan cetak, yang akan berdampak pada terjadinya proses pembelajaran yang minimalis.

Dalam pembelajaran selain metode dan pendekatan yang dipilih harus sesuai dengan karakteristik materi, juga diperlukan pemilihan media yang sesuai guna terjadi proses transfer ilmu. Pengembangan bahan ajar dalam bentuk multimedia pembelajaran menggunakan program yang mudah digunakan serta dipahami baik oleh siswa sebagai pengguna dan guru sebagai fasilitator. Untuk melihat seberapa pentingnya pengembangan media pembelajaran, maka dilakukan analisis kebutuhan dengan menyebarkan angket kepada 30 orang guru produktif di SMK Negeri 3 Medan dan 50 siswa angkatan 2012.
Hasil angket menunjukkan, 95\% guru produktif menyatakan membutuhkan media pembelajaran dalam bentuk multimedia, dan 98\% siswa menyatakan setuju sekali bila bahan ajar/materi pelajaran disajikan dalam bentuk multimedia. Selain itu dari pendapat siswa yang dituangkan dalam angket menyarankan bahwa metode pembelajaran hendaknya dilakukan secara dua arah, artinya siswa diberi kesempatan menyampaikan tanggapan dan guru meresponnya dengan cukup memuaskan.

Pembelajaran dengan mengkaitkan sesuatu hal yang dipelajari dengan kehidupan nyata siswa sangat cocok dengan pembelajaran mikrobiologi, karena pada hakikatnya mikrobiologi harus dengan observasi atau pengamatan yang ada di sekitar lingkungan siswa. Pengetahuan yang bersifat abstrak dalam pembelajaran mikrobiologi sangat sulit untuk dipahami siswa, oleh karena itu dibutuhkan visualisasi dalam rangka untuk pemahaman proses pembuatan media pertumbuhan mikroba yang memang sifatnya sangat abstrak.

Hasil riset oleh Neo Mai dan Ken, tahun 2001 dengan judul Innovative teaching: Using multimedia in a problem-based learning environment menunjukkan hasil yang positif pada kinerja siswa, mampu mendorong siswa untuk berfikir kritis dan aktif dalam proses pembelajaran. Penanaman proses kehidupan dalam proses pembelajaran memang selalu mengalami kesulitan. Hal demikian juga dirasakan oleh guru yang mengajar mata diklat analisis mikrobiologi, mereka merasa kesulitan untuk menciptakan imajinasi yang dapat membuat siswa paham dengan penjelasannya yang berhubungan materi-materi pada mata diklat analisis mikrobiologi sehingga tidak terjadi miskonsepsi atau kesalahan konsep yang berakibat sangat fatal. Dengan Observasi atau pengamatan yang disediakan dalam media pembelajaran yang memberikan gambaran nyata tentang materi, maka perlu adanya keterlibatan seluruh panca indera yang mereka miliki. Dengan demikian maka pengetahuan yang diperoleh siswa akan lebih terserap dan bertahan lebih lama serta lebih bermakna.

Memori tentang pengetahuan tersebut menjadi lebih kuat tersimpan dalam skemataskemata yang terangkai di dalam otak setiap siswa. Melalui keterlibatan seluruh panca indera yang mereka miliki, siswa dapat menyerap materi secara berbeda sesuai dengan kemampuan mereka masing-masing. Pemberdayaan optimal dari seluruh panca 
indera dapat menghasilkan kesuksesan bagi seseorang.

Menurut pendapat Magnesen dalam Dewi Salma (2007:24) bila dikaitkan dengan panca indera, maka daya serap siswa melalui belajar dengan membaca sebanyak $10 \%$, mendengar $20 \%$, melihat $30 \%$, melihat dan mendengar 50\%, mengatakan $70 \%$ dan mengatakan sambil mengerjakan sebanyak $90 \%$.

Hasil penelitian menunjukkan bahwa pengetahuan yang datang lewat indera dengan cara melihat memiliki daya serap $75 \%$, mendengar $13 \%$, dan $12 \%$ lainnya dengan cara mencium, meraba dan merasa. Sumber data lain yang dapat dijadikan pendukung dan memperkuat penelitian ini harus dilakukan adalah data yang diperoleh langsung dari observasi yang dilakukan di SMK Negeri 3 Medan, dari hasil observasi dan wawancara yang dilakukan diperoleh data bahwa multimedia yang dikembangkan oleh guru belum pernah diadakan. Hal ini disebabkan karena terbatasnya perancang multimedia untuk pembelajaran di sekolah menengah.

Dari uraian yang telah dipaparkan ditunjang dengan sumber data yang ada di lapangan, maka perlu diadakannya pengembangan bahan ajar dalam bentuk multimedia yang dapat memberikan visualisasi dari pengetahuan yang sifatnya abstrak menjadi konkrit sehingga tidak terjadi miskonsepsi atau kesalahan konsep. Bila pemahaman siswa terhadap materi yang ada dalam pembelajaran tinggi, diasumsikan berpengaruh besar terhadap hasil belajar dalam hal ini nilai ratarata hasil belajar siswa.

Penelitian ini dibatasi pada pengembangan bahan ajar berbasis multimedia pada mata diklat analisis mikrobiologi. Penelitian ini bertujuan untuk mengetahui apakah bahan ajar berbasis multimedia yang dihasilkan memenuhi syarat sebagai media pembelajaran yang baik serta mengetahui apakah bahan ajar berbasis multimedia yang dihasilkan lebih efektif dibanding dengan pemakaian bahan ajar Modul.

Menurut Brunner seperti yang dikutip oleh Trianto (2011: 15) mengatakan "bahwa belajar suatu proses aktif dimana siswa membangun (mengkonstruk) pengetahuan baru berdasarkan pada pengalaman atau pengetahuan yang sudah dimilikinya".

Sedangkan menurut Burton seperti yang dikutip oleh Rusman (2012: 86) mengartikan bahwa belajar sebagai perubahan tingkah laku pada diri individu berkat adanya interaksi antara individu dengan individu dan individu dengan lingkungannya sehingga mereka dapat berinteraksi dengan lingkungannya. Adapun makna belajar yang terkandung dalam pendapat Burton adalah interaksi. Interaksi ini memiliki makna suatu proses. Intinya bahwa belajar adalah proses.

Dari beberapa pendapat di atas belajar dapat diartikan bahwa sebagai suatu proses mental yang terjadi dalam benak seseorang yang melibatkan kegiatan (proses berfikir) dan terjadi melalui pengalaman belajar yang didapat oleh orang yang belajar melalui reaksi-reaksi terhadap lingkungan dimana dia belajar. Belajar adalah proses perubahan prilaku, dimana perubahan prilaku tersebut meliputi perubahan dalam hal kognitif, afektif, dan psikomotor.

Belajar dapat diselesaikan dengan paling baik bila kegiatan belajar dikaitkan secara langsung dengan pengalaman fisik. Dengan demikian siswa mampu mengingat dengan sangat baik bila fakta dan ketrampilan dilekatkan pada kegiatan yang aktual dan alamiah. Dukungan lain datang dari Dewey dalam Nana Sudjana (2007: 19), lingkungan memberikan masukan kepada siswa berupa bantuan dan masalah, pengalaman yang diperoleh dari lingkungan akan menjadikan kepadanya bahan dan materi guna memperoleh pengertian serta bisa dijadikan landasan pedoman dan tujuan belajar.

Proses pembelajaran dipandang sebagai suatu sistem yang tidak lepas dari komponenkomponen yang saling berinteraksi satu dengan lainnya. Salah satu komponen yang penting adalah sumber belajar yang secara prinsip mencakup pesan, orang, bahan, alat, teknik, dan latar/lingkungan yang mengandung informasi dan dirancang atau dimanfaatkan untuk memfasilitasi seseorang belajar, sehingga memungkinkan siswa untuk belajar secara mandiri.

Menilik definisi tentang sumber belajar tersebut, maka media dapat dikategorikan sebagai bahan dan alat yang dapat mewakili keberadaan guru di dalam kelas dalam proses pembelajaran. Pemanfaatan media adalah penggunaan yang sistematis dari sumber untuk pembelajaran. Namun demikian kedudukan guru tidak dapat digantikan oleh media.

Menurut Atwi Suparman (2001) menyatakan bahwa media hanya merupakan alat untuk menyalurkan pesan atau informasi dari pengirim kepada penerima, sedangkan media tersebut dapat berupa alat-alat elektronik, 
gambar, buku dan sebagainya. Media dapat membantu para siswa dalam mengintergrasikan pengalaman abstrak menjadi pengalaman yang konkret. Begitu pentingnya fungsi media dalam proses pembelajaran sehingga dalam pemilihannya perlu memperhatikan karakteristik dari siswa, isi materi dan desain pembelajaran yang telah diputuskan.

Media dengan pesan yang ada di dalamnya memberikan stimulus berupa informasi dari lingkungan dan direspon oleh register pengindaraan, selanjutnya ada tahap pemrosesan, penyimpanan dan pemanggilan kembali informasi yang telah didapatkan dari otak untuk digunakan kembali bila dibutuhkan. Menurut Mayer (2009: 251) untuk menerapkan prinsip-prinsip berbasis kognitif terhadap desain pesan-pesan instruksional multimedia bisa sangat tergantung pada level pengetahuan yang dicurahkan murid saat mereka menghadapi situasi pembelajaran. Lebih khusus, hal ini menunjukkan cara murid-murid berpengatahuan rendah bisa mendapat lebih banyak manfaat dari penerapan prinsip-prinsip desain ke dalam presentasi multimedia daripada murid-murid yang berpengetahuan tinggi. Garis riset ini menunjukkan bahwa para desainer multimedia perlu mempertimbangkan pengetahuan yang dimiliki mereka yang sedang belajar.

Arsyad (2011: 23) menyatakan bahwa efektifitas proses pembelajaran sangat dipengaruhi oleh faktor metode dan media pembelajaran yang digunakan. Pemilihan Metode mengajar berpengaruh terhadap jenis media yang akan digunakan. Selanjutnya Hamalik (2002: 20) menyatakan bahwa penggunaan media pengajaran sangat membantu keefektifan proses pembelajaran dan penyampaian informasi (pesan dan isi pelajaran). Kehadiran media dalam pembelajaran juga dikatakan dapat membantu peningkatan pemahaman siswa, penyajian data/informasi lebih menarik dan terpercaya serta memudahkan penafsiran data dalam memperoleh informasi.

Dari pendapat dan penjelasan diatas dapat disimpulkan bahwa pada hakikatnya pembelajaran yang efektif merupakan proses pembelajaran yang tidak hanya terfokus kepada hasil yang dicapai peserta didik, namun bagaimana proses pembelajaran yang efektif mampu memberikan pemahaman, kecerdasan, ketekunan, kesempatan dan peningkatan mutu dan dapat memberikan perubahan prilaku serta dapat mengaplikasikannya dalam kehidupan sehari-hari. Untuk mewujudkan pembelajaran yang efektif ditinjau dari kondisi dan suasana serta upaya pemeliharaannya, maka guru selaku fasilitator harus mampu melaksanakan proses pembelajaran secara maksimal.

Mayer (2009: 3) mendefinisikan multimedia sebagai presentasi materi dengan menggunakan kata-kata sekaligus gambargambar, yang dimaksud dengan kata-kata disini adalah materinya disajikan dengan verbal form atau bentuk verbal.

Sedangkan Smaldino $d k k$ (2011: 7) menyatakan "bahwa Media adalah bentuk jamak dari perantara (medium), merupakan sarana komunikasi”. Sementara itu menurut Vaughan seperti yang dikutip oleh Asyhar (2012: 75) mendefinisikan "multimedia merupakan kombinasi dari teks, grafis, seni, suara, animasi, dan video yang dikirimkan oleh komputer atau peralatan elektronik lain". Demikian juga Molenda (2008: 9) berpendapat bahwa "multimedia merujuk kepada berbagai kombinasi dari dua atau lebih format media yang terintegrasi kedalam bentuk informasi atau program instruksi".

Sedangkan menurut Niken dan Haryanto (2010: 26) multimedia pembelajaran dapat diartikan sebagai aplikasi multimedia yang digunakan dalam proses pembelajaran dengan kata lain untuk menyalurkan pesan (pengetahuan, ketrampilan dan sikap) serta dapat merangsang pikiran, perasaan, perhatian dan kemauan pebelajar sehingga secara sengaja proses belajar terjadi, bertujuan dan terkendali.

Menurut Smaldino $d k k$ (2011: 32-47) mengungkapkan bahwa dibutuhkan strategi pembelajaran dalam memadukan teknologi dan media ke dalam jenis demonstrasi, latihan, tutorial, diskusi, simulasi dan penyelesaian masalah. Sedangkan Belawati (2003: 616) menyatakan bahwa pemanfaatan bahan ajar berbantuan komputer pada umumnya digunakan untuk aktifitas pembelajaran yang mendorong siswa untuk belajar secara aktif seperti drill, simulasi, dan permainan. Lebih lanjut Daryanto (2010: 54) menjelaskan multimedia pembelajaran dapat dikategorikan ke dalam lima kelompok yaitu: (1) tutorial, (2) drill dan practice, (3) simulasi, (4) percobaan atau eksperimen, dan (5) permainan.

Didalam penggunaan multimedia memerlukan hardware (perangkat keras) yang berfungsi untuk memfasilitasi penyampaian materi dan software (perangkat lunak) yang berisi program- program yang akan disampaikan. Selain itu dapat pula melibatkan alat-alat lain yang menunjang sistem 
multimedia tersebut agar mendapatkan penyajian audiovisual yang penuh. Multimedia memungkinkan pemakai komputer untuk mendapatkan output dalam bentuk yang lebih kaya dari pada media konvensional.

Perkembangan teknologi yang pesat saat ini telah memungkinkan komputer memuat dan menayangkan beragam bentuk media di dalamnya. Dalam hal ini Heinich $d k k$ (1996: 228) mengemukakan bahwa teknologi komputer tidak hanya digunakan sebagai sarana komputasi dan pengolahan kata (word processor) tetapi juga sebagai sarana belajar multimedia yang memungkinkan peserta didik membuat desain dan rekayasa suatu konsep dan ilmu pengetahuan. Sajian multimedia berbasis komputer dapat diartikan sebagai teknologi yang mengoptimalkan peran komputer sebagai sarana untuk menampilkan dan merekayasa teks, grafik, dan suara dalam sebuah tampilan yang terintegrasi. Dengan tampilan yang dapat mengkombinasikan berbagai unsur penyampaian informasi dan pesan, komputer dapat dirancang dan digunakan sebagai media teknologi yang efektif untuk mempelajari dan mengajarkan materi pembelajaran yang relevan misalnya rancangan grafis dan animasi.

Perkembangan teknologi yang pesat saat ini telah memungkinkan komputer memuat dan menayangkan beragam bentuk media di dalamnya. Dalam hal ini Heinich $d k k$ (1996: 228) mengemukakan bahwa teknologi komputer tidak hanya digunakan sebagai sarana komputasi dan pengolahan kata (word processor) tetapi juga sebagai sarana belajar multimedia yang memungkinkan peserta didik membuat desain dan rekayasa suatu konsep dan ilmu pengetahuan. Sajian multimedia berbasis komputer dapat diartikan sebagai teknologi yang mengoptimalkan peran komputer sebagai sarana untuk menampilkan dan merekayasa teks, grafik, dan suara dalam sebuah tampilan yang terintegrasi.

Dengan tampilan yang dapat mengkombinasikan berbagai unsur penyampaian informasi dan pesan, komputer dapat dirancang dan digunakan sebagai media teknologi yang efektif untuk mempelajari dan mengajarkan materi pembelajaran yang relevan misalnya rancangan grafis dan animasi.

\section{METODE}

Rancangan model penelitian dan pengembangan yang digunakan dalam penelitian ini adalah model pengembangan Borg \& Gall (2003: 570), dengan tahapan sebagai berikut: (1) analisis kebutuhan, (2) analisis instruksional atau perencanaan, (3) mengidentifikasi karakteristik dan ketrampilan awal peserta didik, (4) mengidentifikasi kebutuhan dan tujuan instruksi ke dalam tujuan kinerja spesifik, (5) mengembangkan instrument penilaian, (6)mengembangkan strategi pembelajaran, (7) pengembangan bahan ajar (8) evaluasi formatif terhadap produk antara lain : (a) uji coba kepada ahli, (b) revisi, (c) melakukan uji lapangan (perorangan, kelompok kecil dan kelas terbatas), (d) revisi, dan (9) revisi produk akhir. Setelah penyempurnaan akhir produk, maka langkah selanjutnya dilanjutkan dengan uji efektifitas produk dalam proses pembelajaran.

Prosedur pengembangan adalah sebagai berikut; Tahap pertama melakukan penelitian pendahuluan (analisis kebutuhan) yaitu mengumpulkan informasi (kajian pustaka), identifikasi permasalahan yang dijumpai dalam pembelajaran, dan merangkum permasalahan (studi lapangan). Tahap kedua melakukan perencanaan, dalam desain pembelajaran yaitu indentifikasi tujuan pembelajaran, menetapkan kompetensi dasar, mengindetifikasi karakteristik dan perilaku awal peserta didik, merumuskan indikator, mengembangkan tes acuan patokan, dan menentukan strategi pembelajaran. Tahap ketiga adalah mengumpulkan bahan untuk pengembangan draf produk awal meliputi: pengumpulan bahan, sampai dengan perekaman dan pengumpulan Audio (flowchart, storyboard ). Tahap keempat adalah membuat dan memproduksi multimedia pembelajaran (programming). Tahap kelima melakukan review atau uji lapangan diambil dari hasil evaluasi formatif dan revisi produk.

Desain uji coba dari multimedia pembelajaran pada Kompetensi dasar Media Pertumbuhan Mikroba untuk SMK kelas XI jurusan Kimia Analisis terdiri dari beberapa tahapan yaitu sebagai berikut: (1) Validasi ahli materi pada mata diklat Analisis Mikrobiologi, (2) Validasi ahli desain pembelajaran, (3) validasi ahli media (4) Revisi pengembangan (tahap I), berdasarkan penilaian yang berupa masukkan, kritik atau saran dari tiga ahli, materi, desain dan media; (5) Uji coba perorangan oleh tiga peserta didik ( uji satusatu), (6) Revisi Tahap II (7) Uji coba sembilan orang peserta didik ( uji kelompok kecil); (8) Revisi produk tahap III berdasarkan masukan dan saran pada uji coba kelompok kecil; (9) Uji coba lapangan terhadap 36 orang peserta didik tentang penilaian mengenai daya tarik dan 
kelayakan produk; (10) Revisi produk akhir untuk penyempurnaan; dan dilanjutkan dengan Uji efektifitas produk dalam proses pembelajaran. Subyek uji coba produk dalam penelitian ini adalah ahli materi, ahli desain pembelajaran, ahli media dan siswa kelas XII Jurusan kimia Analisis SMK Negeri 3 Medan yang pernah mengikuti mata diklat analisis mikrobiologi khususnya pada kompetensi dasar media Pertumbuhan Mikroba. Data yang terkumpul dari hasil uji coba produk digunakan sebagai dasar dalam menetapkan kelayakan dan daya tarik terhadap produk yang dikembangkan sebelum dipakai dilapangan. Sesuai dengan desain pengembangan yang dilakukan, jenis data yang digali adalah sebagai berikut ; (a) aspek pembelajaran dan kesesuaian isi yang diperoleh dari ahli materi dan desain pembelajaran; (b) aspek media pembelajaran diperoleh dari ahli media; (c) kualitas tampilan dan penyajian materi, diperoleh dari uji perorangan, kelompok kecil dan uji lapangan; (d) keefektifan media, diperoleh dari hasil belajar pada kompetensi dasar Media Pertumbuhan Mikroba menggunakan bahan ajar berbasis multimedia dengan Strategi Pembelajaran Kooperatif (Cooperative Learning) dibandingkan dengan hasil belajar pada kompetensi dasar Media Pertumbuhan Mikroba dengan menggunakan bahan ajar berupa modul. Selain itu jenis data yang dikumpulkan adalah data kualitatif berupa uraian saran dan masukkan tertulis oleh responden sebagai data tambahan.

Data yang terkumpul dianalisis secara kuantitatif dan kualitatif. Data kuantitatif yang diperoleh dari kuesioner dianalisis dan dikonversikan ke data kualitatif dengan skala 5 kemudian dideskripsikan untuk mengetahui kualitas materi, desain dan media. Data kuantitatif yang diperoleh dari kuesioner dan wawancara dianalisis dengan statistik deskriptif kemudian dikonversikan ke data kualitatif dengan menggunakan skala lima (skala likert).

\section{HASIL DAN PEMBAHASAN \\ Hasil Uji Coba Produk Pengembangan}

Proses pengembangan bahan ajar berbasis multimedia dalam penelitian ini diawali dengan tahap pertama yaitu tahap pembuatan produk awal yang dimulai dengan

1) analisis kebutuhan yaitu suatu analisis yang dilakkan untuk mengetahui perlu tidaknya pengembangan dilakukan. Dari hasil analisis kebutuhan yang dilakukan $97.50 \%$ ) guru dan siswa belum mengenal dan menggunakan perangkat ajar berbasis multimedia dengan program iSpring, dan $2.5 \%$ menyatakan mengenal perangkat ajar berbasis multimedia dengan program iSpring. 93.75\% guru dan siswa setuju bila dalam proses pembelajaran digunakan media pembelajaran dalam bentuk multimedia. $98.75 \%$ sangat membutuhkan bahan ajar berbasis multimedia dalam proses pembelajaran. Selain analisis kebutuhan, dalam analisis desain pembelajaran juga dilakukan analisis frontend yaitu suatu analisis untuk menentukan kesenjangan dan menghasilkan solusi yang berorientasi pada hasil pengembangan produk meliputi sepuluh kegiatan yaitu: Analisis audiens, Analisis Teknologi, Analisis Situasi, Analisis tugas, Analisis kejadian penting, Analisis Tujuan, Analisis Isu, Analisis Media, Analisis data, dan analisis biaya.

2) Tahap perencanaan yaitu kegiatan yang dilakukan untuk menentukan kegiatan menganalisis pembelajaran meliputi identifikasi tujuan instruksional umum, analisis kompetensi pembelajaran, mengidentifikasi tingkah laku masukan dan karakteristik awal siswa, merumuskan Indikator, mengembangkan butir tes acuan patokan, menentukan strategi pembelajaran.

3) Desain dan Pengembangan adalah tahap perancangan media yang akan dibuat Dimulai dari menentukan struktur navigasi, dengan menyiapkan beberapa alternatif bentuk desain-desain tampilan serta materi-materi yang dibutuhkan seperti teks, gambar, animasi, suara, video, dan file presentasi, tahap selanjutnya menyusun flowchart dan storyboard, yang merupakan diafram alur cerita dari bahan ajar multimedia, selanjutnya mengumpulkan materi yang diperlukan untuk pembuatan bahan ajar multimedia meliputi menyusun daftar kebutuhan teks, suara, gambar yang diambil dari berbagai sumber dan disimpan dalam folder yang akan digunakan dalam penyusunan bahan ajar berbasis multimedia.

Materi yang disajikan pada multimedia pembelajaran ini adalah: materi pada kompetensi dasar Media Pertumbuhan Mikroba dikelas XI semester ganjil. Adapun program yang digunakan dalam proses pembuatan produk ini adalah aplikasi powerpoint serta software konverter iSpring untuk tampilan 
dalam bentuk flash, sebagai interface (tampilan), adobe photoshop CS3 untuk mengolah gambar, swift $3 D$ untuk pembuatan $\log$ 3 3 , video converter untuk memotong video. Proses pembuatan program tersebut dapat berjalan dengan lancar, cepat dan lebih tertata karena didasarkan pada flowchart dan storyboard yang telah dipersiapkan serta kesiapan bahan-bahan yang telah dipersiapkan sesuai dengan karakteristik pengguna.

Proses pembuatan program diakhiri dengan mengkaji kembali produk yang dihasilkan dengan mencoba menjalankan program. Bila tidak lagi temukan kesalahan, maka produk siap untuk dilakukan ujicoba.

Uji coba produk dilakukan dengan 3 tahapan yaitu: (1) uji coba dengan meminta validasi kepada ahli materi, ahli desain dan ahli media, (2) uji coba perorangan dengan (3 orang), (3) uji coba kelompok kecil (9 orang), dan (4) uji coba lapangan (35 orang). Hasil akhir produk awal dikemas dalam bentuk compact disk dengan garis besar isinya adalah sebagai berikut:

1. Kompetensi Dasar yang harus dikuasai siswa setelah mempelajari materi yang termuat di dalam CD.

2. Materi yang berisi tentang media pertumbuhan mikroba dengan kajian materi meliputi 5 materi yaitu (1) Nutrisi Dasar Untuk Mikroba, (2) Macam-Macam Media, (3) Sifat-Sifat Media, (4) Komposisi Media, dan (5) LangkahLangkah Pembuatan Media. Pada setiap akhir penyajian materi diberikan latihan soal guna mengukur ketuntasan belajar siswa.Tingkat kemajuan belajar siswa ditentukan oleh keberhasilan mereka dalam mengerjakan soal latihan yang tersedia.

3. Ringkasan yaitu agar siswa lebih mudah memahami dengan membaca kembali ringkasan.

4. Diskusi, disediakn soal untuk didiskusikan bersama kelompok, mengingat strategi yang digunakan adalah strategi pembelajaran kooperatif. 5. Evaluasi yang berisi soal-soal dalam bentuk pilihan berganda untuk mengukur tingkat pemahaman materi yang disajikan.

5. Glossarium, yaitu daftar istilah untuk memudahkan pemahaman materi.

6. Bahan penarik perhatian, berupa gambar, video, dan sound.

7. Pengembang, berisi tentang identitas pengembang.
Deskripsi dari produk media pembelajaran pada tahap diawali dengan sajian petunjuk penggunaan sebelum dimulai belajar serta tampilan teks pembuka "Media Pembelajaran Analisis Mikrobiologi Kelas XI Semester Ganjil" diikuti dengan animasi Globe saat opening program.

Uji validasi produk dilakukan dalam 2 tahap yaitu (1) uji ahli; merupakan validasi yang dilakukan oleh ahli materi pembelajaran, ahli desain pembelajaran dan ahli media pembelajaran. (2) Uji lapangan (perorangan, kelompok kecil, dan kelompok yang lebih besar) dilakukan dengan tujuan untuk mengetahui kualitas media pembelajaran dari sisi keberfungsian program oleh siswa.

Responden pada uji lapangan adalah siswa kelas XII yang sudah pernah mempelajari mata diklat analisis mikrobiologi. Materi dalam CD pembelajaran yang dikembangkan divalidasi oleh dua orang ahli materi yaitu (1) Drs. Yusuf Nasution, M.Si, dosen mikrobiologi Jurusan Biologi FMIPA Universitas Negeri Medan, dan Dra. Martina Restuati, M.Si, dosen mata kuliah mikrobiologi Jurusan Biologi FMIPA Universitas Negeri Medan.

Hasil validasi ahli materi diperoleh dengan memberikan produk dalam bentuk Compact Disk (CD) dan lembar validasi dalam bentuk lembar kuesioner dengan acuan skala linkert. Lembar kuesioner oleh ahli metari termuat dalam 4 aspek yaitu aspek (1) kelayakan isi, (2) penyajian, (3) kebahasaan, dan (4) kegrafikan. Keempat aspek tersebut dijabarkan dalam 17 indikator dengan rincian 6 indikator aspek kelayakan isi, 3 indikator aspek kebahasaan, 2 indikator aspek kegrafikan. Secara rinci perolehan skor pada masing-masing aspek. Secara ringkas hasil validasi ahli materi terhadap bahan ajar yang dikembangkan disajikan pada Tabel 1 berikut:

Tabel 1. Rekap Rerata Perolehan Skor Hasil Validasi Ahli Materi

\begin{tabular}{|c|l|c|c|c|}
\hline No & Aspek & Skor & $\begin{array}{c}\text { Persen } \\
\text { tase }\end{array}$ & $\begin{array}{c}\text { Kriteri } \\
\text { a }\end{array}$ \\
\hline 1 & $\begin{array}{l}\text { Kelayakan } \\
\text { isi }\end{array}$ & 4,75 & $\begin{array}{c}95,00 \\
\%\end{array}$ & $\begin{array}{c}\text { Sangat } \\
\text { Baik }\end{array}$ \\
\hline 2 & Penyajian & 4,44 & $\begin{array}{c}88,85 \\
\%\end{array}$ & $\begin{array}{c}\text { Sangat } \\
\text { baik }\end{array}$ \\
\hline 3 & Kebahasaan & 4,50 & $\begin{array}{c}90,00 \\
\%\end{array}$ & $\begin{array}{c}\text { Sangat } \\
\text { baik }\end{array}$ \\
\hline 4 & Kegrafikan & 4,00 & $\begin{array}{c}80,00 \\
\%\end{array}$ & $\begin{array}{c}\text { Sangat } \\
\text { baik }\end{array}$ \\
\hline & Rerata & 4,42 & 88,45 & Sangat \\
\hline
\end{tabular}




\begin{tabular}{|l|l|l|l|l|}
\hline & & & $\%$ & baik \\
\hline
\end{tabular}

Pada tabel di atas, rekap rerata skor hasil validasi oleh ahli materi secara umum kualitas media pembelajaran yang dikembangkan dalam kriteria sangat baik dengan rerata skor sebesar 4,42 Adapun komentar dan saran dari hasil validasi guna revisi produk dapat dirangkum sebagai berikut: (1) Kelayakan isi disarankan penambahan materi tentang laju pertumbuhan bakteri dan masukkan kurva pertumbuhan bakteri. Membuat variasi soal dalam bentuk gambar atau grafik, (2) Penyajian disarankan membuat teks pada tampilan video pembelajaran dan diberi durasi waktu agak lama agar siswa dapat menyimak/mencatat, (3) Kebahasaan diharapkan suara yang lebih jelas dan sedikit berimprovisasi. Hasil keseluruhan dari proses validasi oleh ahli materi selanjutnya dianalisis dan digunakan sebagai dasar untuk membuat revisi pertama pada media pembelajaran yang dikembangkan sehingga diperoleh

hasil yang lebih baik dari sebelumya. Validasi Desain pembelajaran pada penelitian ini dilakukan untuk mengetahui apakah desain sudah sesuai dengan tujuan dari pembelajaran. Validasi ahli desain pembelajaran dilakukan oleh dua orang yaitu Prof. Dr. Sahat Siagian, M.Pd dan Prof. Dr. Harun Sitompul, M.Pd keduanya merupakan dosen pascasarjana Universitas Negeri Medan. Ahli desain pembelajaran memvalidasi produk terhadap aspek: (1) kelayakan isi meliputi kualitas desain pembelajaran, (2) aspek penyajian meliputi kualitas desain informasi dan kualitas interaksi, (3) aspek kegrafikan meliputi kualitas presentas Tabel 3. Rekap Rerata Hasil Validasi Ahli Media

\begin{tabular}{|c|l|c|c|c|}
\hline No & Aspek & Skor & $\begin{array}{c}\text { Persen } \\
\text { tase }\end{array}$ & Kriteria \\
\hline 1 & $\begin{array}{l}\text { Pemrogra } \\
\text { man }\end{array}$ & 4,00 & $\begin{array}{c}80,00 \\
\%\end{array}$ & $\begin{array}{c}\text { Sangat } \\
\text { Baik }\end{array}$ \\
\hline 2 & $\begin{array}{l}\text { Kualitas } \\
\text { Teknis }\end{array}$ & 3,78 & $\begin{array}{c}75,70 \\
\%\end{array}$ & baik \\
\hline & Rerata & 3,89 & $\begin{array}{c}77,80 \\
\%\end{array}$ & baik \\
\hline
\end{tabular}

Hasil validasi oleh ahli media selain diperoleh data secara kuantitatif juga data secara diskriptif dalam bentuk saran dan komentar demi perbaikan media pembelajaran yang iyang kesemuanya dijabarkan dalam 22 indikator.

Secara ringkas hasil validasi ahli desain pembelajaran terhadap bahan ajar yang dikembangkan disajikan pada Tabel 2 berikut:

Tabel 2. Rekap Rerata Perolehan Skor Hasil Validasi Ahli Desain Pembelajaran

\begin{tabular}{|c|c|c|c|c|}
\hline No & Aspek & $\begin{array}{c}\text { Sko } \\
\text { r }\end{array}$ & $\begin{array}{c}\text { Persen } \\
\text { tase }\end{array}$ & $\begin{array}{c}\text { Kriteri } \\
\mathrm{a}\end{array}$ \\
\hline 1 & $\begin{array}{l}\text { Desain } \\
\text { pembelajaran }\end{array}$ & $\begin{array}{c}4,8 \\
8\end{array}$ & $\begin{array}{c}97.75 \\
\%\end{array}$ & $\begin{array}{c}\text { Sangat } \\
\text { Baik }\end{array}$ \\
\hline 2 & $\begin{array}{l}\text { Desain } \\
\text { informasi }\end{array}$ & $\begin{array}{c}4,5 \\
0\end{array}$ & $\begin{array}{c}90.00 \\
\%\end{array}$ & $\begin{array}{c}\text { Sangat } \\
\text { baik }\end{array}$ \\
\hline 3 & $\begin{array}{l}\text { Desain } \\
\text { interaksi }\end{array}$ & $\begin{array}{c}4,6 \\
2\end{array}$ & $\begin{array}{c}92.50 \\
\%\end{array}$ & $\begin{array}{c}\text { Sangat } \\
\text { baik }\end{array}$ \\
\hline 4 & $\begin{array}{l}\text { Desain } \\
\text { presentasi }\end{array}$ & $\begin{array}{c}4,7 \\
1\end{array}$ & $\begin{array}{c}94.20 \\
\%\end{array}$ & $\begin{array}{c}\text { Sangat } \\
\text { Baik }\end{array}$ \\
\hline & Rerata & $\begin{array}{c}4,6 \\
8\end{array}$ & $\begin{array}{c}93.61 \\
\%\end{array}$ & $\begin{array}{c}\text { Sangat } \\
\text { baik }\end{array}$ \\
\hline
\end{tabular}

Validasi media dalam penelitian ini dilakukan dengan tujuan untuk mengetahui kualitas media pembelajaran yang dikembangkan. Validasi ahli media dilakukan oleh dua orang ahli yaitu Prof. Dr. H.M. Badiran, M.Pd dan Prof. Dr. Abdul Hamid K, M.Pd, keduanya merupakan dosen pascasarjana di Universitas Negeri Medan. Hasil validasi berupa skor penilaian multimedia pembelajaran pada Mata Diklat Analisis Mikrobiologi terhadap aspek pemrograman dan aspek kualitas teknis atau tampilan. Kedua aspek selanjutnya dijabarkan dalam 15 indikator. Secara ringkas rekap rerata hasil validasi oleh ahli media terhadap bahan ajar dikembangkan disajikan pada tabel 2.

dikembangkan. Adapun saran dan komentar dari ahli media sebagai berikut:

1. Aspek pemrograman diharapkan agar icon untuk eksekusinya khas dan mudah dipilih serta mudah disarankan membuat program tersebut mudah dieksekusi menjadi Auto Run begitu CD imasukkan langsung dibaca dan dieksekusi untuk membuka program. Hasil perolehan data kuantitatif dan kualitatif yang diperoleh dari hasil validasi ahli media dianalisis dan digunakan sebagai dasar untuk membuat revisi pertama terhadap produk yang dikembangkan.

Proses pelaksanaan uji coba produk bertempat di SMK Negeri 3 Medan pada jurusan Kimia Analisis. Uji coba produk meliputi 3 tahap yaitu uji coba perorangan, kelompok kecil dan uji coba 
lapangan. Untuk uji coba perorangan, siswa yang menjadi subjek penelitian adalah siswa yang memiliki prestasi tinggi satu orang, berprestasi sedang satu orang dan siswa berprestasi rendah satu orang. Tujuan dari uji coba perorangan adalah untuk mengidentifikasi kekurangan dari produk pembelajaran setelah divalidasi oleh ahli serta telah dilakukan revisi. Penilaian dan saran dari uji coba perorangan ini adalah pada aspek kualitas materi pembelajaran dan aspek kualitas teknis atau tampilan yang terdapat multimedia pembelajaran pada mata diklat Analisis Mikrobiologi.

Tabel 4. Rekap Hasil Rerata Uji coba Perorangan terhadap Kualitas Media Pembelajaran Analisis mikrobiologi.

\begin{tabular}{|c|l|c|c|c|}
\hline No & Aspek & Skor & $\begin{array}{c}\text { Persenta } \\
\text { se }\end{array}$ & Kriteria \\
\hline 1 & $\begin{array}{l}\text { Kualitas } \\
\text { materi }\end{array}$ & 4,70 & $94.18 \%$ & $\begin{array}{c}\text { Sangat } \\
\text { Baik }\end{array}$ \\
\hline 2 & $\begin{array}{l}\text { Kualitas } \\
\text { Teknis }\end{array}$ & 4,57 & $91.47 \%$ & $\begin{array}{c}\text { Sangat } \\
\text { Baik }\end{array}$ \\
\hline & Rerata & 4,63 & $92,82 \%$ & $\begin{array}{c}\text { Sangat } \\
\text { Baik }\end{array}$ \\
\hline
\end{tabular}

Perhitungan secara keseluruhan dari tanggapan siswa pada uji coba perorangan terhadap kualitas media pembelajaran yang dikembangkan diperoleh rerata skor 4,63 dengan kriteria sangat baik. Komentar juga diberikan oleh siswa pada saat mereka selesai mencoba menggunakan $\mathrm{CD}$ pembelajaran yang dikembangkan. Seluruh siswa menyatakan bahwa materi media pembelajaran analisis mikrobiologi lebih mudah dipahami karena adanya visualisasi dari proses analisis mikrobiologi pada pembeuatan media nutrient agar yang disajikan melalui video pembelajaran.

Konsep yang disajikan mudah diikuti. Mereka juga merasa terpacu untuk belajar lebih baik. Hasil uji coba perorangan ini tidak ada masukan atau saran, sehingga tidak ada revisi kedua, dan dapat dilanjutkan untuk uji coba kelompok kecil. uji coba produk pada kelompok kecil dilakukan terhadap 9 orang siswa yang terdiri dari tiga siswa berprestasi tinggi, tiga siswa berprestasi sedang, dan tiga siswa berprestasi rendah.

Data yang dihasilkan pada uji coba kecil ini bertujuan untuk mengetahui kekurangan dan kelemahan dari produk multimedia pembelajaran yang akan digunakan dan merupakan uji coba sebelum produk di uji cobakan ke lapangan.

Tabel 5. Rekap Hasil Rerata Uji coba kelompok kecil terhadap Kualitas Media Pembelajaran Analisis mikrobiologi.

\begin{tabular}{|c|l|c|c|c|}
\hline No & Aspek & Skor & $\begin{array}{c}\text { Persenta } \\
\text { se }\end{array}$ & Kriteria \\
\hline 1 & $\begin{array}{l}\text { Kualitas } \\
\text { materi }\end{array}$ & 4,72 & $94.44 \%$ & $\begin{array}{c}\text { Sangat } \\
\text { Baik }\end{array}$ \\
\hline 2 & $\begin{array}{l}\text { Kualitas } \\
\text { Teknis }\end{array}$ & 4,54 & $90.79 \%$ & $\begin{array}{c}\text { Sangat } \\
\text { Baik }\end{array}$ \\
\hline & Rerata & 4,63 & $92,61 \%$ & $\begin{array}{c}\text { Sangat } \\
\text { Baik }\end{array}$ \\
\hline
\end{tabular}

Pada uji coba kelompok kecil ini terdapat perbaikan dan saran yang dapat dirangkum sebagai berikut: yaitu memasukkan kegiatan siswa pada waktu praktik sebagai dokumentasi pada multimedia pembelajaran agar dapat lebih memotivasi siswa.

Hasil perolehan data kuantitatif dan kualitatif yang diperoleh dari hasil uji coba kelompok kecil dianalisis dan digunakan sebagai dasar untuk membuat revisi ketiga terhadap produk yang dikembangkan.

Kemudian dilanjutkan dengan uji coba lapangan. Pada uji coba lapangan ini, yang menjadi subyek ujicoba adalah siswa kelas XII yang pernah mempelajari materi yang sama namun masih menggunakan modul sebagai bahan ajar. Pada uji coba kali ini mereka dijadikan subyek penelitian untuk mengukur kelayakan dari produk yang dikembangkan.

Tabel 6. Rekap Hasil Rerata Uji coba lapangan terhadap Kualitas Media Pembelajaran Analisis mikrobiologi.

\begin{tabular}{|c|l|c|c|c|}
\hline $\begin{array}{c}\mathrm{N} \\
\mathrm{o}\end{array}$ & Aspek & Skor & $\begin{array}{c}\text { Persen } \\
\text { tase }\end{array}$ & Kriteria \\
\hline 1 & $\begin{array}{l}\text { Kualitas } \\
\text { materi }\end{array}$ & 4,66 & $\begin{array}{c}93.26 \\
\%\end{array}$ & $\begin{array}{c}\text { Sangat } \\
\text { Baik }\end{array}$ \\
\hline 2 & $\begin{array}{l}\text { Kualitas } \\
\text { Teknis }\end{array}$ & 4,63 & $\begin{array}{c}92.78 \\
\%\end{array}$ & $\begin{array}{c}\text { Sangat } \\
\text { Baik }\end{array}$ \\
\hline & Rerata & 4,65 & $\begin{array}{c}93.02 \\
\%\end{array}$ & $\begin{array}{c}\text { Sangat } \\
\text { Baik }\end{array}$ \\
\hline
\end{tabular}

Dari hasil penilaian terhadap multimedia pembelajaran terhadap aspek kualitas materi pembelajaran dan aspek kualitas teknis atau tampilan pada ujicoba lapangan secara keseluruhan menunjukkan kriteria "Sangat Baik", dengan rerata skor 4,65. 
Pada tahap uji coba lapangan ini tidak ada saran atau masukkan sehingga revisi keempat tidak dilakukan. Tahap akhir adalah penyempurnaan produk menjadi produk akhir. Produk akhir selanjutnya digunakan untuk mengukur efektifitas penggunaan media pembelajaran melalui proses pembelajaran dengan menggunakan dua kelas sebagai sampel. Kelas yang terpilih akan menggunakan media pembelajaran dalam bentuk CD sebagai bahan ajar, akan dibandingkan dengan kelas yang menggunakan modul sebagai bahan ajar.

\section{Hasil Uji Efektifitas Produk Pengembangan}

Uji keefektifan produk dilakukan untuk mengetahui keunggulan dari produk yang dikembangkan dengan produk yang selama ini digunakan dalam proses pembelajaran. Dalam hal ini produk yang dihasilkan adalah CD pembelajaran dalam bentuk multimedia pembelajaran pada Mata Diklat Analisis Mikrobiologi yang digunakan sebagai bahan ajar.

Bahan ajar dalam bentuk media pembelajaran digunakan pada kelas yang telah terpilih melalui pengundian sebagai kelas yang menggunakan multimedia pembelajaran yaitu kelas XIKA2 melalui proses pembelajaran dengan menggunakan strategi pembelajaran kooperatif selama 2 kali pertemuan.Proses pelaksanaan uji efektifitas produk diawali dengan pretest dan diakhiri post test dari kedua kelas yang dijadikan sebagai kelas ujicoba

Tabel 7. Rekap Hasil Belajar Siswa yang diajar dengan Media Pembelajaran dan Modul

\begin{tabular}{|l|c|c|}
\hline Nilai & $\begin{array}{c}\text { Kelas Dengan Media } \\
\text { Pembelajaran }\end{array}$ & $\begin{array}{c}\text { Kelas Dengan Bahan Ajar } \\
\text { Modul }\end{array}$ \\
\hline Terendah & 77 & 70 \\
\hline Tertinggi & 97 & 90 \\
\hline Ketuntasan & $100 \%$ & $85,72 \%$ \\
\hline Rerata & 88,91 & 82,03 \\
\hline Peningkatan hasil belajar (\%) & $8,38 \%$ & $7,73 \%$ \\
\hline
\end{tabular}

Tabel 7 menunjukkan bahwa perolehan rerata hasil belajar kelas yang menggunakan media pembelajaran lebih tinggi dibanding dengan kelas yang menggunakan modul dengan perbedaan rerata hasil belajarnya sebesar 6,88 dari perolehan skor post test antara dua kelas.

Perbedaan presentase peningkatan hasil belajar dengan rombel yang tidak menggunakan media pembelajaran yang dikembangkan sebesar $0,65 \%$. Untuk mengetahui tingkat signifikansi perbedaan kedua kelas maka pada skor kedua kelas dilakukan uji t test. Hasil perhitungan menunjukkan $\mathrm{t}$ hitung $=11,80>\mathrm{t}$ tabel $=1,67(\alpha=0,05 ; \mathrm{n}=70)$. Dengan demikian diperoleh simpulan bahwa ada perbedaan yang signifikan antara kelas yang menggunakan media pembelajaran dengan kelas yang menggunakan modul sebagai bahan ajar.

Dalam proses validasi produk bersumber dari data validasi oleh ahli materi dapat diketahui bahwa kualitas media yang dikembangkan termasuk dalam kategori sangat baik. Secara visual hasil validasi dari ahli materi dapat dilihat pada gambar 1 .

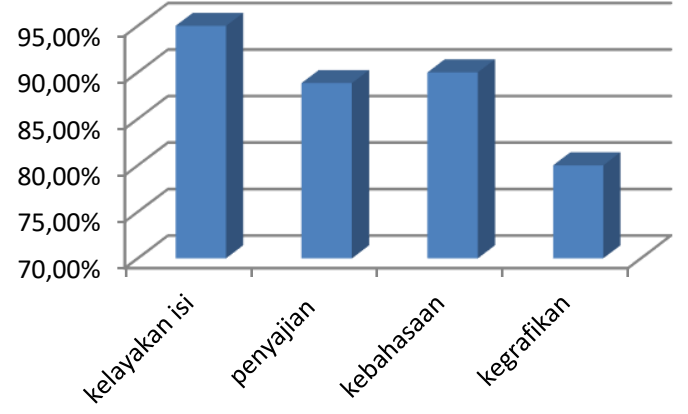

Gambar 1.Persentase Hasil Validasi

Ahli Materi

Pada gambar 1 tampak adanya persentase aspek kelayakan isi lebih tinggi daripada yang lain. Hal ini disebabkan pada aspek kelayakan isi ada 4 indikator yang dinilai sangat baik yaitu Ketepatan cakupan materi, kebenaran konsep, kesesuaian dengan kurikulum, ketepatan urutan materi pembelajaran. Dengan demikian bahwa CD pembelajaran yang dikembangkan dari segi kualitas materi telah layak digunakan sebagai bahan ajar yang baik. 
Dalam proses validasi produk bersumber dari data validasi oleh ahli desain pembelajaran dapat diketahui bahwa kualitas media yang dikembangkan termasuk dalam kategori sangat baik. Secara visual hasil validasi dari ahli desain dapat dilihat pada gambar 2.

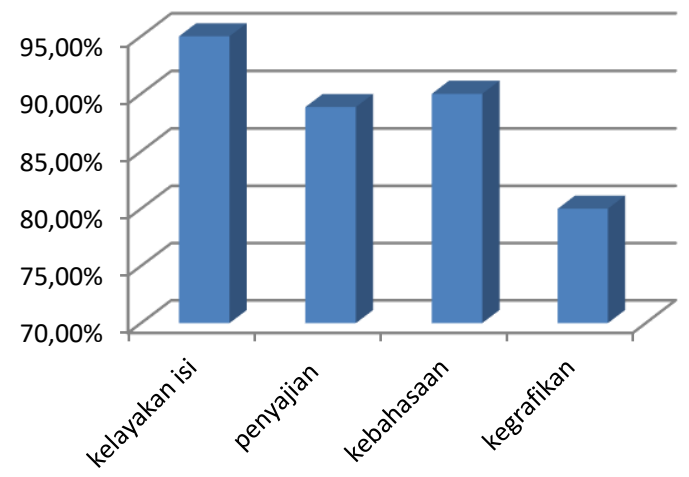

Gambar 2.Persentase Hasil Validasi Ahli Desain Pembelajaran

Penilaian ahli desain pembelajaran terhadap aspek kualitas desain interaksi menunjukkan persentase rata-rata $92,50 \%$, dan masuk dalam kriteria sangat baik, artinya pengaturan isi pembelajaran memperhatikan aspek interaksi antara siswa dengan materi pembelajaran dapat menciptakan suatu kondisi yang mampu memberikan pengalaman belajar serta memfasilitasi pembelajaran. Sedangkan persentase rata-rata aspek kualitas desain presentasi dari multimedia pembelajaran menunjukkan persentase $92,20 \%$, termasuk dalam kriteria sangat baik, artinya desain presentasi pada multimedia pembelajaran memiliki tampilan yang menarik sehingga mampu menimbulkan ketertarikan siswa untuk melakukan pembelajaran.

Hasil validasi ahli media dapat diketahui bahwa kualitas media yang dikembangkan termasuk dalam kategori baik. Secara visual persentase hasil validasi ahli madia dapat dilihat pada gambar 3

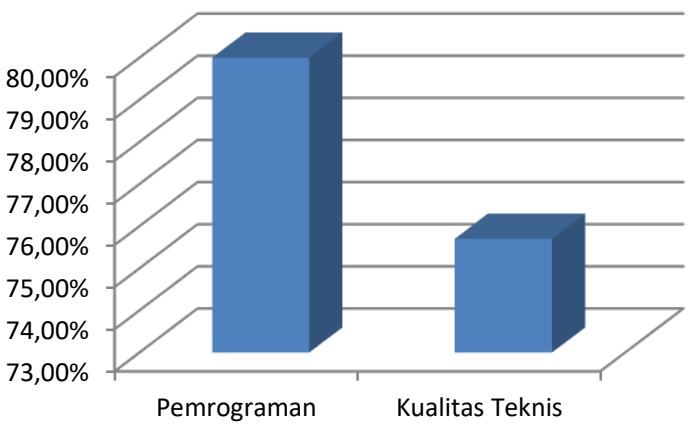

Gambar 3.Persentase Hasil Validasi Ahli Media

Pada gambar 3, aspek pemrograman memperoleh persentase yang lebih tinggi dibanding aspek kualitas teknis. Hal ini disebabkan karena pada aspek tampilan ada 6 indikator yang mendapatkan penilaian sangat baik yaitu (1) Konsistensi dengan alur program,(2) Keberlanjutan program, (3) Efisiensi system, (4) Ketepatan display, (5) Pengelolaan disk dan (6) Konsistensi antar bagian pelajaran. Dengan demikian desain pada aspek pemrograman sesuai dengan kualitas media yang baik. Visualisasi kualitas produk secara keseluruhan pada uji coba produk melalui tahap uji perorangan, kelompok kecil dan uji lapangan dapat dilihat pada gambar 4

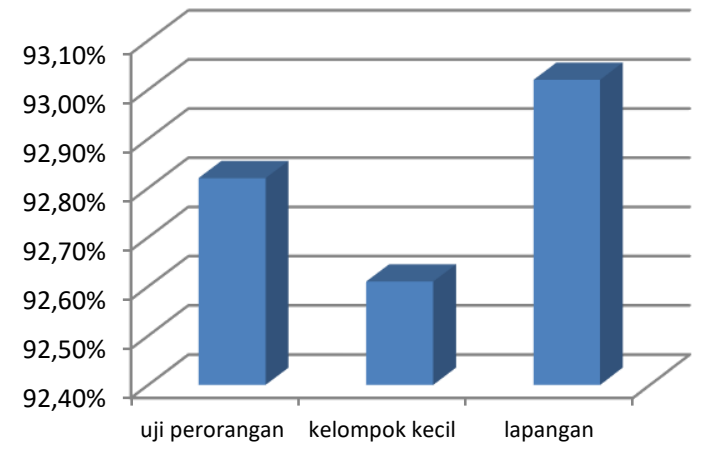

Gambar 4. Kualitas Produk dalam Uji coba perorangan, kelompok kecil dan uji coba lapangan

Bersumber dari gambar 4 maka diperoleh simpulan bahwa dalam uji kelompok kecil ada yang harus dilakukan revisi. Setelah dilakukan revisi maka hasil yang terlihat pada uji coba lapangan menunjukkan peningkatan yang lebih baik baik dari kualitas materi maupun kualitas teknis. Dengan demikian maka produk yang dikembangkan telah layak dan baik untuk digunakan sebagai bahan ajar dan dapat dijadikan sebagai sumber belajar dalam proses pembelajaran analisis mikrobiologi.

Pada aspek desain pembelajaran mendapat respon yang paling tinggi dari aspek yang lain. Hal ini terjadi karena pada aspek desain pembelajaran terdapat 3 indikator yang mendapat respon sangat baik, yaitu (1) Ketepatan pemilihan topik konsep media pertumbuhan mikroba, (2) Kesesuaian materi dengan indikator pembelajaran latihan dan 
evaluasi guna pencapaian kompetensi, (3) Pemberian latihan, (4) Konsistensi tes dengan indikator pembelajaran. Aspek lain yang sangat mendukung adalah kekuatan media untuk membangkitkan motivasi belajar. Aspek lain yang mendapat tanggapan sangat baik adalah aspek media. Hal ini disebabkan karena siswa memberi respon sangat baik pada 5 indikator yaitu (1) konsistensi navigasi yang digunakan, (2) ketersediaan video dalam kemudahan memahami materi, (3) kualitas teks (mudah untuk dibaca), (4) komposisi dan kombinasi warna, (5) kemudahan CD untuk digunakan Dengan demikian dapat disimpulkan bahwa media pembelajaran yang dikembangkan memberi kemudahan dalam hal penggunaannya dan pemahaman materi analisis mikrobiologi.

Uji coba produk juga menunjukkan hasil yang positif dengan adanya peningkatan yang signifikan pada hasil belajar siswa yang ditunjukkan dengan uji t test. Hal ini berarti bahwa langkah pengembangan yang dilakukan merupakan hal yang sangat tepat. Adanya tahap revisi memberikan kualitas media pembelajaran yang dikembangkan menjadi semakin baik ditinjau dari aspek media, aspek materi, aspek media dan aspek ketahanan produk.

ada saat proses validasi produk siswa tidak merasa kesulitan menjalankan program, bahkan mereka termotivasi untuk mempejari pesan yang ada di dalamnya dan lebih mudah memahami konsep yang diberikan dibanding tanpa menggunakannya dalam proses belajar. Produk media pembelajaran yang dikembangkan didesain dengan navigasi linier, karena materi dalam analisis mikrobiologi merupakan materi bersyarat. Materi bersyarat artinya materi pertama menjadi prasyarat bagi materi kedua dan seterusnya.

Media ini juga didesain dengan pemberian batas ketuntasan minimal 70 pada setiap latihan yang ada pada setiap materi. Dengan demikian penguasaan terhadap materi menjadi lebih terkontrol. Bila latihan pada materi satu tidak mencapai ketuntasan maka siswa tidak bisa lanjut ke materi berikutnya. Spesifikasi dari media pembelajaran yang dikembangkan adalah teks dengan gambar, video dengan teks yang merupakan visualisasi dari proses pembuatan media pertumbuhan mikroba, yang tidak dapat digantikan hanya dengan informasi verbal semata. Visualisasi proses analisis mikrobiologi dikemas dalam bentuk teks dan gambar serta grafik dan video dan didesain untuk siswa. Hal ini merupakan suatu kelebihan dari media ini.
Namun demikian dibalik kelebihan ada keterbatasan yang tidak dapat dihindari. Keterbatasan yang masih dijumpai adalah bahwa di dalam media pembelajaran belum cukup mengakomodir strategi pembelajaran kooperatif, hal ini disebabkan terbatasnya kemampuan dalam mendesain program, sehingga perlu penelitian lebih lanjut serta pengembangan program.

Selain itu Uji coba produk multimedia pembelajaran mata diklat Analisis Mikrobiologi hanya dilakukan secara terbatas dengan sampel 35 siswa jurusan Kimia Analisis di SMK Negeri 3 Medan T.A.2013/2014. Uji coba luas tidak dilakukan, sehingga faktor bias masih mungkin mempengaruhi hasil penelitian. Oleh karena itu, sampel pada penelitian harus lebih representatif agar hasil penelitian dapat digeneralisasikan.

Keterbatasan sarana dan prasarana dan kemampuan peneliti dalam pembuatan multimedia pembelajaran khususnya fasilitas audio video yang dimiliki peneliti tentunya akan memberi pengaruh dalam upaya pengembangan produk.

Kesiapan siswa untuk terlibat dalam suatu media pembelajaran yang baru dan berbeda dengan media pembelajaran yang biasa mereka gunakan juga berpengaruh terhadap proses pembelajaran. Ketidaksiapan siswa ini diatasi dengan mengkopi multimedia pembelajaran ke dalam flash disk agar dapat digunakan sebagai alat untuk dapat belajar mandiri maupun berkelompok.

\section{PENUTUP \\ Simpulan}

Berdasarkan hasil penelitian yang diperoleh dapat disimpulkan bahwa media pembelajaran yang dikembangkan layak digunakan sebagai bahan ajar dan salah satu alternatif sumber belajar yang dapat digunakan dalam proses pembelajaran analisis mikrobiologi. Pembelajaran dengan menggunakan media pembelajaran terbukti lebih efektif disbanding dengan pemakaian modul.

\section{Saran}

Berdasarkan hasil penelitian dan kesimpulan pada pengembangan bahan ajar berbasis multimedia diharapkan guru menggunakan hasil pengembangan bahan ajar pada mata diklat analisis mikrobiologi disekolah menjadi salah satu alternatif sumber belajar yang dapat 
digunakan, serta guru-guru termotivasi untuk dapat mengembangkan media pembelajaran pada pembelajaran mata diklat lain.

\section{DAFTAR PUSTAKA}

Arsyad, A. 2013. Media Pembelajaran. Edisi Revisi. Jakarta: PT Raja Grafindo Persada.

Asyhar, Rayandra. 2012. Kreatif Mengembangkan Media Pembelajaran. Jakarta: Referensi

Atwi Suparman. 2001. Desain Instruksional: Mengajar diPerguruan Tinggi. Jakarta: PAU-PPAI, Universitas Terbuka

Belawati, Tian, dkk. 2003. Pengembangan Bahan Ajar. Jakarta. Pusat Penerbitan Universitas Terbuka

Borg, W.R., Gall, M.D., \& Gall, J.P. 2003. Educational research. An introduction (7thed.). New York: Longman.

Daryanto, 2012. Media Pembelajaran. Bandung: Sarana Tutorial Nurani Sejahtera.

Hamalik, Oemar. 2002. Media Pendidikan. Bandung; Alumni.

Mayer, Richard E. 2009. Multimedia learning: Prinsip-prisip dan aplikasi.Penerjemah:Teguh Wahyu utomo. Yogyakarta: Pustaka Pelajar

McLaughlin, J., Arbeider, D. A. 2008. Evaluating multimedia-learning tools based on authentic research data that teach biology concepts and environmental stewardship. Contemporary Issuesin Technology and Teacher Education, 8(1).Diambil tanggal 18 februari 2014. http://www.citejournal.org/vol8/iss1/scie nce/article1.cfm

Munadi,Yudhi. 2013. Media Pembelajaran; Sebuah Pendekatan Baru. Jakarta. Referensi : GP Press Group.

Neo, M., \& Ken T. K. Neo, Ken, T.K. 2001. Innovative teaching: Using multimedia in a problem-based learning environment. Educational Technology \& Society 4(4) 2001 ISSN 1436-4522, 19-30. Diambil tanggal $20 \quad$ Januari 2014. http://www.ifets. info/others/download_pdf.php?j_id=12\& a_id $=166$

Padmo Dewi. 2004. Teknologi Pembelajaran: PeningkatanKualitas Belajar melalui Teknologi Pembelajaran. Jakarta: Pusat
Teknologi Komunikasi dan Informasi Pendidikan

Rusman. 2012. Belajar dan Pembelajaran Berbasis Komputer. Bandung; Alfabeta

Smaldino, S.E., Lowther, D.L., \& Russel, J.D. 2011. Instructional techonolgy and media for learning(9thed.). Diterjemahkan oleh Kencana Prenada Media Group. Jakarta: Kencana Prenada Media Group.

Sudarmanto Dwi, Widya Yetty KS. \& Ekawati Yuni. 2006. Multimedia Interaktif Sebuah Terobosan Pembelajaran Paket B. Jurnal Ilmiah PTK-PNF, 1(1), 46-56. 